\title{
E-Government Project Evaluation Based on the Theory of Life-cycle Management
}

\author{
Wan Wang \\ School of Government \\ Beijing Normal University \\ Beijing, PR. China \\ 1176575602@qq.com
}

\author{
Yunpeng Ge \\ School of Business Management \\ Beijing University of Posts and Telecommunications \\ Beijing, PR. China
}

\begin{abstract}
Conducting an e-government project evaluation is an important way to circumvent risks and improve the success rate of the e-government project. At present, China's egovernment project evaluation mainly focuses on post-evaluation, which is performance evaluation but lacks the life-cycle evaluation, resulting in a high project failure rate and low return on investment. This paper is mainly talking about the construction of e-government projects evaluation based on the life-cycle theory. Dividing e-government projects construction into four stages: project preparation, project bidding, project implementation and project operation and maintenance. Starting from the four core stages of the e-government projects, a new closed-loop evaluation index is put forward to make the egovernment project evaluation more convincing and scientific.
\end{abstract}

Keywords-e-government; project management; performance evaluation; life-cycle management

\section{INTRODUCTION}

In the 1990s, the rapid development of Internet-connected technologies provided an excellent opportunity for the development of e-government in various countries. Egovernment has greatly improved the administrative efficiency of the government. Thus, the central and local governments of China are also attaching great importance to the construction of e-government projects and have invested a large amount of money on it.

At the same time as the rapid development of e-government, its problems have gradually emerged. Whether large-scale construction and investment generate a return proportional to input has become a problem that is gradually receiving more and more attention. The World Bank has published the report China's Information Revolution: Promoting Economic and Social Transformation, which shows that China's e-government projects have begun to take shape in terms of telecommunications infrastructure, networks and databases, but low-level repeated construction, and unfinished projects are common. Because of the low return on e-government projects investment, the Chinese government attaches great importance to the evaluation of e-government performance.

At present, China's e-government project life-cycle evaluation is very few. The evaluation mainly focuses on the performance evaluation after the completion of the project acceptance, that is, post evaluation. Post-evaluation can't carry out the full life cycle dynamic evaluation of the project from project approval, bidding, construction, operation and maintenance, which is not conducive to the dynamic monitoring and risk control of the project. In order to monitor the whole process of the e-government project, find out problems in time and make the adjustment, it is very important to introduce the theory of life-cycle management into e-government project evaluation.

\section{LITERATURE REVIEW}

At present, the academic research on the life-cycle evaluation of e-government projects is still lacking, but there are abundant researches on the performance evaluation of egovernment and the theory of life-cycle management.

\section{A. E-government Performance Evaluation Practice}

In 2002, the United States launched the Performance Reference Model (PRM) in government activities. PRM includes six evaluation aspects: tasks and business results, customer results, processes and activities, human capital, technology and other fixed assets[1]. Canada's e-government performance evaluation index system is constructed from three levels: output, impact and result. The output includes portability, accessibility and credibility. The impact level includes personal privacy, user satisfaction and benefit. The result level includes service maturity, service acceptability, service transformation, security and personal privacy.[2] The United Nations conducts project evaluation from the egovernment readiness index and e-participation index. Egovernment readiness index is the weighted average of data communication infrastructure index, human resource index, online service scope and quality index. E-participation index includes e-information, e-decision and e-consultation.[2] Waseda University of Japan conducts E-government Performance Evaluation for dozens of countries. The evaluation indicators are mainly based on the interface function application, infrastructure, management efficiency, portal website, e-government promotion, e-participation, etc.[3] Chengfu Zhang (2004) divided the current methods of egovernment performance evaluation into five types: "focusing on website evaluation", "focusing on resource efficiency", "focusing on software and hardware integration", "focusing on social network effectiveness" and "focusing on public value and service orientation"[4].

To sum up, based on the research status of e-government project performance evaluation, it can be found that it's developing towards more and more institutionalized and standardized direction, but there are still some shortcomings: 
the e-government project is closely linked and faced with subjective or objective risks. Problems in one stage may lead to a series of problems, and post-evaluation is not conducive to the feedback and adjustment of the project in the implementation process. Second, large-scale e-government projects often last for a very long period, some even for several years. In this case, it is impractical for the improvement of project construction to carry out performance evaluation after the completion of the project, and the early investment of the project is likely to become the sunk cost. The life-cycle evaluation of the project can avoid the obstacles brought by the long project cycle to the evaluation work.

The implementation of the life-cycle evaluation of egovernment projects can effectively avoid various risks brought by performance assessment, which is the requirement of scientific management of e-government projects. The life-cycle evaluation of a project should start from the decision-making of project initiation, to the needs analysis, feasibility analysis, project design and planning, bidding management, project construction and implementation, project closing acceptance, project operation and maintenance for a life cycle assessment, deepen the closed cycle life cycle management mode of egovernment projects, and build from the project initiation to the end of the project. In the process from project approval to project completion, a perfect working mechanism of "feedback, rectification, feedback, improvement" shall be established, the organic connection between project evaluation and administrative accountability shall be well done, and the correction mechanism shall be improved. Problems shall be found in each stage of project implementation, and timely feedback shall be given. Corresponding solutions shall be taken, and the project shall be dynamically adjusted.

\section{CONSTRUCTION OF LIFE-CyCle EVAluATION INDEX OF E-GOVERNMENT PROJECT}

According to the stage division of project management, the life cycle of the e-government project is divided into three stages: project approval preparation stage, bidding stage, implementation stage and operation and maintenance stage. Starting from the four stages of the e-government project, combined with the objectives of each stage, the life-cycle evaluation system of the e-government project is constructed (TABLE I). are serious drawbacks in performance evaluation, which may even lead to project failure and a large number of sunk costs. The reasons lie in the following two aspects: first, each stage of

TABLE I. E-GOVERNMENT PROJECT LIFE-CyClE EVALUATION INDEX

\begin{tabular}{|c|c|c|c|}
\hline Project stage & First Level Index & Second Level Index & Index Interpretation \\
\hline \multirow{4}{*}{$\begin{array}{l}\text { Project preparation } \\
\text { stage }\end{array}$} & \multirow{4}{*}{ Feasibility study } & Demand identification & Is the project construction necessary. \\
\hline & & Target orientation & Whether the target orientation of the project is accurate. \\
\hline & & Preliminary plan & Whether the plan can achieve the expected economic and social benefits. \\
\hline & & Fund Raising & Whether the source of project funds is guaranteed. \\
\hline \multirow{3}{*}{$\begin{array}{l}\text { Project } \\
\text { bidding } \\
\text { stage }\end{array}$} & Bidding process & Process standardization & Whether the bidding process conforms to the specification. \\
\hline & \multirow{2}{*}{ Tender evaluation } & $\begin{array}{l}\text { Qualification of } \\
\text { contractor }\end{array}$ & Whether the contractor has the corresponding qualification. \\
\hline & & $\begin{array}{c}\text { Proposal } \\
\text { of contractor }\end{array}$ & Whether the scheme provided by the contractor feasible. \\
\hline \multirow{2}{*}{$\begin{array}{c}\text { Project } \\
\text { implementation stage }\end{array}$} & \multirow{2}{*}{$\begin{array}{l}\text { Achievement of phased } \\
\text { objectives }\end{array}$} & Progress control & Whether the phased objectives in project implementation are completed on time. \\
\hline & & Quality Control & $\begin{array}{c}\text { Whether the phased objectives in the project implementation are completed } \\
\text { according to the quality. }\end{array}$ \\
\hline
\end{tabular}




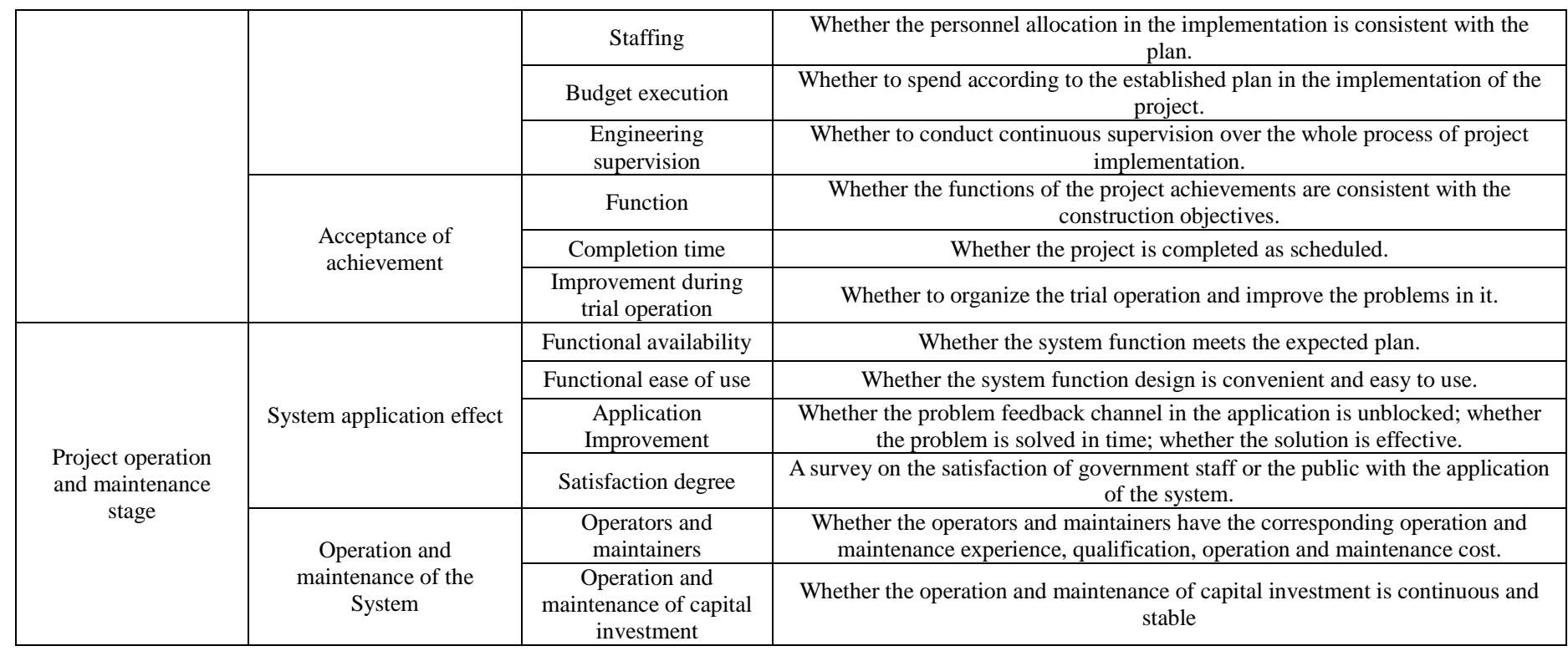

First, the most important work in the preparation stage of egovernment project is to analyze the feasibility of the project. Therefore, the first level evaluation index of the project is feasibility study, which includes four aspects: demand identification, target positioning, preliminary scheme formulation and fund raising.

Secondly, the bidding stage of e-government projects determines whether the whole project can be successfully implemented. In order to achieve this goal, first, we must strictly follow the standardized bidding process and choose contractors in a fair, just and open way. Secondly, the evaluation of contractors in bid evaluation and determination should focus on the qualification of many bidding contractors and the construction scheme they provide. Therefore, the indicators set at this stage include standardization of the bidding process, qualification of contractors, and contractor scheme.

Third, in the process of e-government project implementation, the contents to be evaluated include the achievement of the phased objectives of the project and the project construction results. In the implementation stage of the project, the contractor needs to gradually complete the tasks of each stage according to the stage division of the project. The contents to be evaluated include the project progress, project construction quality, project staffing, project safety management and whether the project supervision is carried out in accordance with the requirements of the original scheme. When the construction of the project is near the end, the acceptance of the project results shall be organized, in which it is necessary to evaluate whether the functions of the project results meet the requirements of the original plan, whether the completion time of the project is up to the standard, and whether the problems in the acceptance stage of the project are improved. Therefore, the indicators set in this stage include progress control, quality control, staffing, safety management, supervision, functional integrity, completion time, trial operation improvement.
Fourthly, e-government projects enter into the operation and maintenance stage after acceptance. The main focus of the operation and maintenance stage is the application effect and system operation and maintenance. In the application effect, we should focus on the evaluation of functional availability, functional ease of use, system stability, application improvement and satisfaction. In terms of operation and maintenance, we should focus on two aspects: the qualification of the operator and the investment of operation and maintenance funds.

\section{THE WORKFLOW OF LIFE CYCLE E-GOVERNMENT PROJECT EVALUATION}

After the construction of the e-government life-cycle evaluation index, the project evaluation work needs to be carried out according to a certain process, including index system design, index data collection and expert scoring, result in statistics and analysis. The first stage is the design of the index system. In this stage, we need to fully investigate the background of the e-government project, design the index system according to the background of the project and the index framework. After the design is completed, the informatization department should organize experts to evaluate and modify the index system, and finally, form a suitable egovernment project evaluation index.

The second stage is the collection and scoring of index data. By following up on the development of the project, monitoring the achievement of the phased objectives of the project, collecting the information needed for the evaluation, and then organizing the expert group to score the project, we can get the score of each phase of the project construction. At the same time, in the process of project evaluation, we need to feedback the problems in the project construction in time, and correct them in time to prevent the problems from spreading.

The third stage is the result of statistics and analysis. After the project enters the operation and maintenance stage, the project evaluation is also coming to an end. It is necessary to make statistics on the evaluation results of the whole life cycle 
Define the corresponding objectives of each stage of project preparation, bidding, implementation, operation and maintenance, and determine the evaluation indicators of each stage to monitor the achievement of the objectives of each stage. According to the phased evaluation results, the problems in the process of e-government project construction are dynamically adjusted to achieve the goal of "promoting construction by evaluation”.

\section{REFERENCES}

[1] Baker D L, "Advancing e-government performance in the United States through enhanced usability benchmarks", Government Information Quarterly, 2009, 26(1): 82-88.

At present, China's e-government construction is faced with the risk of high investment and low return. The rate of repeated construction is high and the rate of resource integration is low. In order to guide the construction of China's e-government projects, it is necessary to carry out the e-government project evaluation. China has carried out many effective exploration and practice in e-government performance evaluation, but the evaluation of e-government projects have not yet started. Most of the evaluation of e-government performance evaluation is post-evaluation. In order to improve the success rate of the project and realize the dynamic monitoring of the project during the construction process, a set of evaluation index system based on the life cycle management of the project is needed to guide the project evaluation.

In order to improve the return on investment, this paper starts from the life cycle of e-government projects, and combines the theory of project management to carry out the dynamic evaluation of the life-cycle of e-government projects. and ways forward”, Government information quarterly, 2007, 24(3): 646-665.

[3] Seng Wong $\mathrm{M}$, Hideki N, George $\mathrm{P}$, “The use of importanceperformance analysis (IPA) in evaluating Japan's e-government services”, Journal of theoretical and applied electronic commerce research, 2011, 6(2): 17-30.

[4] Chengfu Zhang, Jun Tang, "E-government Performance Evaluation: model comparison and substance analysis”. China Administration, 2004, 5: 21-23 (In Chinese). Pedersen, H. K. Stranddorf, K. Christiansen, and G. Rebitzer, "Life Cycle Management-Report for the SETAC Europe Working Group”, Society of Environmental Toxicology and Chemistry, Pensacola/Brussels, 2003.

[6] Morris L N. Critical path: "construction and analysis”, L. N. Morris. 1967.

[7] Barry W. Boehm. "Understanding and Controlling Software Costs", Software Engineering IEEE Transactions on, 1988, 14(10):1462-1477.
[2] Yildiz M, “E-government research: Reviewing the literature, limitations,

[5] Hunkeler, D., K. Saur, A. A. Jensen, W. P. Schmidt, M. Finkbeiner, C. S 